\title{
DETERMINANTS OF SHARIA INSURANCE COMPANY PROFITABILITY
}

\author{
Maman Suherman $^{1}$, Irman Firmansyah ${ }^{2 *}$, and Medina Almunawwaroh ${ }^{3}$ \\ 1,2,3 Universitas Siliwangi, Tasikmalaya, Indonesia
}

\begin{abstract}
The growth of sharia insurance in Indonesia continues to occur. This is a sign that the people in Indonesia have good risk management because the company's growth is supported by the increase in customers in sharia insurance companies. This condition must be supported again by the conditions in which the company has a good performance, so the company must find a way to continue to improve its performance. This study is aimed to determine the effect of leverage, firm size, and company age on the financial performance of sharia companies. The method used is through quantitative research using multiple regression. The method of data collection uses a purposive sampling technique carried out to all populations, namely all Islamic insurance companies in Indonesia from 2012 to 2018. The results of the study show that leverage and age of the company do not succeed in influencing financial performance, while firm size has a positive effect on financial performance. Therefore it is important for companies to continue to increase their assets, especially in collecting funds from the public as the company's ingredients in managing their finances to improve their financial performance.
\end{abstract}

Keywords: Age, Financial Performance, Leverage, Size

\section{INTRODUCTION}

The business potential of sharia insurance companies is still very large in a country that has a Muslim majority population. The existence of a conventional insurance company that has long been established is not able to provide inner satisfaction for some people because it is felt to have given a big burden for people who join the conventional company. There is no balance between costs and benefits for the insurance participant community, resulting in insurance companies having a heavy burden to continue to maintain their customers. Therefore, the presence of Islamic insurance is a cure for public discomfort in conventional insurance transactions.

Related to its current existence, sharia insurance companies must have good performance in order to be able to survive and meet the needs of the community, because the main purpose of the establishment of a company is to obtain profits through its potential. So that the greater the profits obtained, the better the company's operations (Firmansyah, 2017). Good performance improvement will show that the sharia insurance business has been successfully implemented, especially in developing countries. Therefore the existence of the management ranks will greatly influence the success of the company's business, especially in improving its financial performance because it will control the potential of the company's resources at that time. so as to provide certainty of its existence in Islamic insurance, research is needed.

The first step that must be known is to determine the size of the company's performance. Financial report analysts usually use financial ratios as a tool to measure performance. One commonly used is the ratio of return on assets (ROA). Therefore, this study will focus on financial performance on the ROA ratio. This ratio focuses on the company's ability to earn profits seen from the assets it has. So that the strength of the company will be drawn to obtain benefits from every activity carried out through the source of wealth held for a certain period.

*Corresponding author. Email address : irmanfirmansyah@unsil.ac.id 
A more important factor is not only the high financial performance that has been obtained at this time but what factors are causing an increase in financial performance. This is because if the company does not know what are the factors that cause a rise in financial performance if one-day financial performance is going down, management does not know which factors cause the decline in financial performance.

According to the results of the collection of literature studies, one of the factors thought to influence the company's financial performance is a capital structure (leverage). Capital structure is the ratio between debt and equity. This ratio is used to determine the number of funds provided by creditors with the owner of the company so that this ratio serves to find out every rupiah of its own capital which is used as collateral for the debt. This ratio is illustrated by the Debt to Equity Ratio (DER), namely the higher this ratio indicates the higher the risk of failure that may occur in the company, and vice versa if the lower the ratio shows the lower the risk of failure that might occur to the company. But the high and low risk is usually directly proportional to the profits to be obtained so that the ratio will have an impact on financial performance. This is in accordance with the results of Stein's (2012) study which states that DER has a negative effect on profitability. While the research of Hidayat \& Firmansyah (2017), Usman (2003) and Tobing (2006) states that ratios leverage has a positive effect on the level of profitability.

In addition to the above factors, other factors that are thought to influence the company's financial performance are assets. Companies that have large assets are usually more flexible in obtaining financial performance compared to companies that have small assets. As has been proven by the research of Hidayat \& Firmansyah (2017) and Almajali et al (2012) shows that size has a positive effect on company performance.

Other factors that influence performance are the age of the company. Age is thought to influence profitability according to several studies that have proven it (Almajali et al, 2012; Alomari \& Azzam, 2017; Batrinca \& Burca, 2014; Rich, 2015). Companies that have a longer age have more experience so they are better able to control the company in order to improve company performance. However, this must be further proven through a study, especially on sharia insurance companies that are currently developing.

Therefore, considering the good Islamic insurance companies in Indonesia are experiencing development, it is very urgent to do research on the factors that cause the high and low financial performance of Islamic insurance companies so that the upward trend of company assets can be maintained. So that this research will re-examine the influence of variables of leverage, size (assets) and age on financial performance in sharia insurance companies in Indonesia.

\section{LITERATURE REVIEW}

\subsection{Agency Theory}

In relating the ownership structure to the bank's performance, there is one thing that cannot be separated from the achievement of the bank's organizational goals and its performance, namely the management or bank management. Achieving the goals and performance of the bank is inseparable from the performance of the management itself. In connection with this, the relationship between the management of a bank and the owner of the bank will be stated in a contract (performance contract). The contractual relationship between the owner and the management is in line with the Agency Theory (Jensen and Meckling, 1976).

An agency relationship is defined as a contract where one or more people (called owners or shareholders or owners) appoint another person (called an agent or manager/management) to do some work on behalf of the owner. The work includes delegating authority to make decisions. In this case, the management is expected by the owner to be able to optimize the available resources in the bank to the maximum. If both parties maximize their role (utility maximizers), it is reasonable if management will not always act in the interests of the owner. This is very reasonable because owners 
generally have welfare motives a long-term, whereas management is more short-term in nature, so sometimes they tend to maximize profit in the short term regardless of the sustainability of long-term profits. To limit or reduce this possibility, the owner can set appropriate incentives for management, namely by issuing monitoring costs in the form of salary.

\subsection{Financial Performance}

One way that is used to assess a company's financial performance is by looking at its profitability ratio. Profitability can be measured by return on assets (ROA). ROA is a comparison between profit before tax and total assets in a period, the formula used to look for ROA is as follows:

$$
\mathrm{ROA}=\mathrm{x} 100 \%
$$

ROA is calculated based on the ratio of profit before tax and average total assets. Because the results of the operation you want to measure, profit before interest and tax are used. Assets used to measure the ability to obtain operating profit are operating assets. Companies with relatively large total assets will have better performance because they have total revenue relatively large as a result of increased product sales. With the increase in total revenue, it will increase company profits so that financial performance will be better (Mawardi, 2005)

\subsection{Factors that Influence Financial Performance}

\subsubsection{Capital Structure (Leverage)}

The DER ratio is a fundamental measure in corporate finance, which can show the company's financial strength. This ratio is the ratio between equity and debt, where debt includes long-term, short-term, and current liabilities.

The funding policy reflected in the debt-equity ratio (DER) greatly influences the achievement of profits obtained by the company. Ang (1997) in Priharyanto (2009) states that the higher the DER will affect the amount of profit (return on assets) achieved by the company. If the cost of debt reflected in borrowing costs is greater than the cost of own capital, then the average cost of capital (weighted average cost of capital) will be greater so that return on assets (ROA) will be smaller, and vice versa.

This high ratio indicates that the company will have real problems in the long run, one of which is the possibility of bankruptcy. The greater the debt the greater the risk is borne, even though in circumstances where the company can very well manage its debt, then the existence of debt will provide a good opportunity for the company to be able to increase profits or profits.

The higher the DER shows the greater the trust of outsiders, this is very possible to improve the performance of the company, because, with large capital, the opportunity to reach the level of profit is also large. Thus the effect of DER on ROA is positive. This is supported by a pecking order theory that establishes a sequence of funding decisions where managers will first choose to use retained earnings, then debt, and external self-capital as a last resort Priharyanto (2009).

The results of the study by Priharyanto (2009), Usman (2003) and Tobing (2006) show that financial leverage measured by the DER ratio has a positive effect on profitability as measured by ROA. Whereas Stein (2012) research shows that DER has a negative effect on ROA.

Based on the theory and the results of the above research, it is assumed that the capital structure has a positive effect on financial performance, the hypothesis is:

H1: capital structure has a positive effect on the financial performance of sharia insurance companies 


\subsubsection{Company Size}

The size of a company is a scale, which can be classified as small according to various ways. At the company's size(size)are more likely to be seen from the total asset power companies in the operations is of total assets, while the assets are sourced from debt and equity capital. A company with large assets has the possibility to generate greater profits. Research results of Alper \& Anbar (2011), Hidayat \& Firmansyah (2017); Almajali et al (2012); Menicucci \& Paolucci (2016); Mehari \& Aemiro, (2013); Rashid \& Kemal (2018) shows a relationship between size and performance. Therefore based on the results of the study predicted that the size (size) can affect the performance of Islamic insurance companies. So the second hypothesis is:

H2: The size of the company has a positive effect on the financial performance of Islamic insurance companies

\subsubsection{Company Age}

The age of the company is a measure where the distance of time is measured when the company began to stand until now. Companies that have a long life will have more knowledge and experience in running the company's operations so that they will enjoy more in managing the company's resources. This has been proven by several studies, namely Almajali et al, 2012), Alomari \& Azzam (2017), Batrinca \& Burca (2014) and Rich (2015) which indicate a relationship positive between age and company performance. This means that the greater the age, the better the company's performance. Therefore, the third hypothesis is:

H3: The age of the company has a positive effect on the financial performance of Islamic insurance companies

\section{RESEARCH METHODS}

\subsection{Population and Samples}

This study used a population of sharia sector insurance companies in Indonesia from 2011 to 2017. The entire population used a purposive sampling method to select samples to be used in this study. Population retrieval took in that period with consideration due to the limitations of researchers in obtaining data. Sharia insurance companies were sampled as many as 6 Islamic insurance companies in Indonesia (Takaful Insurance, Jaya Proteksi Takaful, Sonwelis Insurance Company, Al-Amin Sharia Life Insurance, Family Takaful Insurance, Amanahjiwa Life Insurance Giri Artha).

\subsection{Research Variables}

This study uses 2 types of variables, namely:

1. Independent variable

a. Capital structure is measured by Debt to Equity Ratio (DER).

The formula used to calculate Leverage or DER (Debt to Equity Ratio) is as follows:

$$
\text { DER= }=\frac{\text { Total Debt }}{\text { Equity }}
$$

b. Company size measured by total assets or total assets

c. The age of the company (Age) is measured by the length of the company standing

2. Dependent Variable. In this study, the dependent variable used is Return on Asset. Return on assets describes a company's ability to generate net income through the use of a number of assets.

The formula used to calculate ROA is as follows:

Earning After Tax

$$
\text { ROA = ------------------------ x 100\% }
$$




\subsection{Data Analysis Methods}

Data processing methods used in this study are panel data which is a combination of data time series and cross-section. Panel data can be processed if it has criteria ( $\mathrm{t}>$ $1)$ and $(n>1)$. The swing model will be used, namely through the ordinary least square (OLS) approach after going through data quality testing.

\section{RESEARCH RESULTS AND DISCUSSION}

\subsection{Research Results}

For the data collected by the research results on sharia insurance companies in Indonesia, 5 Islamic insurance companies in Indonesia were obtained in 2018. From a number of sharia insurance companies, the next step is to collect data in accordance with predetermined criteria. Then the sample is determined according to the research requirements, namely the sharia insurance company that publishes annual financial reports from 2012 to 2018, namely Al-Amin Sharia Life Insurance, Giri Artha Life Insurance, Jaya Proteksi Takaful, Family Takaful Insurance, General Takaful Insurance, and Airline Insurance Sonwelis.

\subsection{Test of Classical Assumptions}

Based on the data from the research that has been collected, the classic assumption test is done first to see the quality of the data to ensure that the data is worth testing the hypothesis. Classical assumption testing consists of a normality test, multicollinearity test, and heteroscedasticity test.

\section{Normality Test}

A good regression model is one that has a normal or near-normal distribution. Which is intended to test whether the independent variable (bound) and the dependent variable (free) in the regression model have a normal distribution or not. Tests for normal distribution were carried out by the Kolmogorov-Smirnov test. If the value of Asymp. Sig (2-tailed) is greater than 0.05 , then the data is declared to be normally distributed.

Based on the results of the analysis, it is known that the value of Asymp. Sig (2tailed) which is 0.091 . This value is greater than 0.05 or $5 \%$. So thus it is concluded that the data is declared to be normally distributed and it can be said that the regression model meets the normality assumption so that the data is feasible to use.

\section{Multicollinearity Test}

Multicollinearity test data can be done with a correlation matrix by looking at the magnitude of the VIF value (variance inflation factor) and tolerance value. A regression model that is free from multicollinearity has a VIF number around 1 and tolerance numbers close to number 1 or no more than number 10 . The multicollinearity test results show that the VIF value of each independent variable in Islamic insurance companies in Indonesia is around number 1 (less than number 10). And the tolerance value (TOL) obtained shows a value greater than 0.10 . From these results, it can be seen that the regression model is free from multicollinearity between independent variables.

\section{Heteroscedasticity Test}

To detect the presence or absence of heteroscedasticity, the Glejser Test is used. The analysis results show that the sig value. all independent variables are greater than 0.05 . This shows that there are no symptoms of heteroscedasticity in the regression model in this study. 


\subsection{F Test}

Data analysis used in this study is by analyzing Ordinary Least Square (OLS) panel data with the help of SPSS. To determine the accuracy of the model (goodness of fit) the influence of the independent variables namely DER, Size, and Age on the dependent variable, namely financial performance measured by ROA, F test is carried out.

Here is the SPSS output of F test data analysis of sharia insurance companies in Indonesia with regression analysis OLS approach panel data:

Table 1 Results of Model Accuracy Test Calculation

\begin{tabular}{cccccc}
\hline & Sum of & & & & \\
Model & Squares & Df & Mean Square & F & Sig. \\
\hline Regression & 156,796 & 3 & 52,265 & 2,510 &, $048^{\mathrm{b}}$ \\
Residual & 624,656 & 30 & 20,822 & & \\
Total & 781,453 & 33 & & & \\
\hline Source: SPSS Output (data processed) & & & &
\end{tabular}

Based on the table above, the results show that the significance value is 0.048 or smaller than the significance value limit $(\alpha=0.05)$. The results of this study indicate that in order to explain the variable financial performance (ROA), then the variable AGE, DER, and Size can be used together because the model is feasible to use.

\subsection{Test of Individual Parameter Significance (Test Statistics t)}

Furthermore, to test the hypothesis that has been proposed, it is done using the ttest. This test is conducted to determine whether the independent variables partially have a significant effect on the dependent variable. Based on the results of testing using the regression analysis tool obtained the following results:

Table 2 Results of Test Calculation $\mathrm{t}$

\begin{tabular}{|c|c|c|c|c|c|}
\hline & $\begin{array}{l}\text { Unstandardized } \\
\text { Coefficients }\end{array}$ & $\begin{array}{l}\text { Standardized } \\
\text { Coefficients }\end{array}$ & $\begin{array}{l}\text { Unstandardized } \\
\text { Coefficients }\end{array}$ & & \\
\hline Model & B & Std. Error & B & $\mathrm{t}$ & Sig. \\
\hline DER &,- 756 &, 772 &,- 198 &,- 979 &, 335 \\
\hline Ln_SIZE & 2,451 & , 906 &, 581 & 2,705 &, 011 \\
\hline$\overline{\mathrm{A} G E}$ &,- 166 &, 112 &,- 297 & $\begin{array}{c}- \\
1,486\end{array}$ &, 148 \\
\hline
\end{tabular}

Source: SPSS Output (data processed)

Based on the results of the analysis in table 2 above it can be concluded that the capital structure (DER) does not affect the financial performance of Islamic insurance companies in Indonesia, the size of the company has a positive effect on the financial performance of Islamic insurance companies in Indonesia, and the age of the company does not affect financial performance in sharia insurance companies in Indonesia. Therefore the hypothesis that is accepted is only the second hypothesis, while the first and third hypotheses are rejected.

The results of the research and processing of the data above found several very important and unique findings. This happens because the scope of the research is carried out in sharia insurance companies, which on average stand not long ago and have characteristics that are different from the company in general.

In this study, it is proved statistically that the capital structure as measured by the Debt to Equity Ratio (DER) does not have an effect on financial performance as measured by return on assets. Return on assets is one measure used by many researchers to measure the financial performance of a company. This is because ROA is able to 
describe the strength of company assets in generating profits in a certain period. So that the greater the ROA, the better the financial performance.

According to several empirical studies, DER has a positive effect on ROA, so the proposed hypothesis shows that DER has a positive effect on ROA. But it is different from the results of this study which found that DER did not affect ROA. Based on the collected data shows that the profits owned by Islamic insurance companies in Indonesia on average are negative so that financial performance is negative. This turned out to provide a different picture from other types of companies that negative financial performance (ROA) does not mean the company has poor performance because not a few other researchers use other measures as a proxy for the financial performance of sharia insurance companies.

DER owned by a sharia insurance company shows a capital structure ratio that the greater the DER, the greater the debt it has compared to the existing capital. This ratio does not have any impact on ROA. So that it is not in accordance with previous studies (Priharyanto, 2009; Usman, 2003; Tobing, 2006; Miyajima, 2003; and Stein, 2012). Therefore it is necessary to examine other factors that are thought to be determinants of ROA other than DER.

The second variable, namely the size of the company indicates an influence on financial performance. Large companies certainly have more freedom in running their business so that the management of existing funds in the company is more flexible and this statistically has a good impact on the ROA ratio. It is evident that the size of the company has a positive influence on ROA which means that the larger the size of the company, the better the performance of the company. This is in accordance with previous studies namely Alper \& Anbar (2011), Hidayat \& Firmansyah (2017); Almajali et al (2012); Menicucci \& Paolucci (2016); Smirlock (1985), Bikker and Hu (2002) and Guillen et al. (2014), Mehari \& Aemiro, (2013); Rashid \& Kemal (2018).

The third variable is the age of the company. This study proves that there is no influence on the age factor of the company on financial performance as measured by ROA. Currently, in Indonesia, the majority of sharia insurance companies have not been established for a long time, although there are several companies that have been established for more than 20 years. However, the results of the statistical tests provide information that sharia insurance companies that have a long life or those who have a young age are still not able to provide companies with ROA ratios, so this study is not in accordance with some previous studies such as Almajali et al, 2012), Alomari \& Azzam (2017), Batrinca \& Burca (2014) and Rich (2015) which show a positive relationship between age and company performance.

\section{CONCLUSIONS, LIMITATIONS AND RECOMMENDATIONS}

Based on the results of the research and discussion in the previous chapter, this research can be summarized as follows:

1. The capital structure as measured by the Debt to Equity Ratio does not affect financial performance as measured by return on assets

2. The size of the company as measured by the Debt to Equity Ratio has a positive effect on financial performance as measured by return on assets

3. The age of the company as measured by the Debt to Equity Ratio does not affect financial performance as measured by return on assets

After seeing the results of this study accompanied by the completeness of the data obtained, the authors feel that there are many limitations that can disrupt the results of research, including the variables used as a measure of financial performance in Islamic insurance using ROA with a negative average value each year so that other variables need to be which can be used to measure the financial performance of Islamic insurance.

From these limitations, the suggestions conveyed are that the researcher can then replace the dependent variable and add another independent variable that is predicted to influence financial performance. Also, further research can be carried out by 
comparing the two types of insurance companies, namely Islamic insurance and conventional insurance.

\section{References}

Almajali, A. Y., Alamro, S.A., \& Al-Soub, Y. Z. (2012). Factors Affecting the Financial Performance of Jordanian Insurance Companies Listed at Amman Stock Exchange. Journal of Management Research, 4(2)

Alomari, M., \& Azzam, I. (2017). Effect of the micro and macro factors on the performance of the listed jordanian insurance companies. International Journal of Business and Social Science, 8(2), 66-73.

Alper, D., \& Anbar, A. (2011). Bank Specific And Macroeconomic Determinants of Commercial Bank Profitability: Emprical Evidence from Turkey. Journal Business and Economics. Vol.2, Numb.2, pp: 139-152.

Batrinca, G., \& Burca, A. (2014). The determinants of financial performance in romanian insurance market. International Journal of Academic Research in Accounting, Finance, and Management Sciences, 4(1), 299-308.

Firmansyah, I. (2017). Comparison Analysis Of Influence Of Current Ratio On Financial Performance. Jurnal Akuntansi, 12(2)

Hidayat, I. P., \& Firmansyah, I. (2017). Determinants Of Financial Performance In The Indonesian Islamic Insurance Industry. Etikonomi, 16(1)

Jensen, M. C., \& Meckling, W. H. (1976). Theory of the Firm : Managerial Behavior, Agency Costs and Ownership Structure. Journal of Financial Economics, Oktober, 1976, 3(4), pp. 305-360.

Kaya, E.Ö. (2015). The effects of firm-specific factors on the profitability of non-life insurance companies in turkey. International Journal of Financial Studies, 3(4), 510-529.

Mawardi, W. (2005). Analisis Faktor-Faktor Yang Mempengaruhi Kinerja Keuangan Bank Umum Di Indonesia (Studi Kasus Pada Bank Umum Dengan Total Asset Kurang Dari 1 Triliun). Jurnal Bisnis Strategi, 14(1)

Mehari, D., \& Aemiro, T. (2013). Firm specific factors that determine insurance companies' performance in ethiopia. European Scientific Journal, 9(10), 245-255.

Menicucci, E., \& Paolucci, G. (2016). Factors affecting bank profitability in Europe: an empirical investigation. African Journal of Business Management 10 (17): 410 420. https://doi.org/10.5897/AJBM2016.8081

Priharyanto, B. (2009). Analisis Pengaruh Current Ratio, Inventory Turnover, Debt to Equity Ratio, dan Size Terhadap Profitabilitas. [Thesis]. UNDIP

Rashid, A., \& Kemal, M.U. (2018). Impact of internal (micro) and external (macro) factors on profitability of insurance companies. Journal of Economic Policy Researches, 5(1), 35-57.

Stein, E. T. (2012). Pengaruh Struktur Modal (Debt Equity Ratio) Terhadap Profitabilitas (Return On Equity). Skripsi, Program Strata 1 Manajemen, Fakultas Ekonomi dan Bisnis Universitas Hasanuddin, Makassar.

Tobing, T. S. M. (2006). Pengaruh Struktur Modal Terhadap Profitabilitas Pada Industri Makanan dan Minuman Yang Tercatat di Bursa Efek Jakarta. [Skripsi]. 
Program Strata 1 Manajemen, Fakultas Ekonomi Universitas Sumatera Utara, Medan

Usman, B. (2003). Analisis Rasio Keuangan dalam Memprediksi Perubahan Laba pada Bank-Bank di Indonesia. Media Riset Bisnis \& Manajemen, 3(1) 